This item was submitted to Loughborough's Research Repository by the author.

Items in Figshare are protected by copyright, with all rights reserved, unless otherwise indicated.

\title{
Sophie's choice: social attitudes to welfare state retrenchment in bailed-out Portugal
}

PLEASE CITE THE PUBLISHED VERSION

http://dx.doi.org/10.1080/14616696.2015.1035299

PUBLISHER

(C) Taylor \& Francis

VERSION

AM (Accepted Manuscript)

\section{PUBLISHER STATEMENT}

This work is made available according to the conditions of the Creative Commons Attribution-NonCommercialNoDerivatives 4.0 International (CC BY-NC-ND 4.0) licence. Full details of this licence are available at: https://creativecommons.org/licenses/by-nc-nd/4.0/

\section{LICENCE}

CC BY-NC-ND 4.0

\section{REPOSITORY RECORD}

Valadez, Laura, and F. Carreira da Silva. 2015. "Sophie's Choice: Social Attitudes to Welfare State Retrenchment in Bailed-out Portugal”. Loughborough University. https://hdl.handle.net/2134/17246. 


\title{
Sophie's Choice: Social Attitudes to Welfare State Retrenchment in Bailed-Out Portugal
}

Filipe Carreira da Silva ${ }^{1}$ and Laura Valadez-Martinez ${ }^{2}$

\begin{abstract}
This article examines social attitudes towards social rights in Portugal. It utilizes original survey data from 2013 to study the distribution of welfare attitudes in a context of economic austerity and welfare retrenchment. The main argument is that there are at least two sources of preference-formation regarding public social provision: one is universalistic (or needsbased), the other is contributory. These two logics frame choices concerning the future of the welfare state in Portugal. We explore the determinants of this choice through three hypotheses: dualization between insiders and outsiders (H1); the type of welfare regime $(\mathrm{H} 2)$, and social rights consciousness (H3). Our findings suggest that choice between universalistic and contributory models is not impervious to macro-institutional factors and labour market performance. The paper's main contribution, however, is to empirically demonstrate that this choice is significantly shaped by pre-existing understandings of social rights in Portugal, namely its politically contested character.
\end{abstract}

\section{Keywords}

Welfare attitudes; social rights; social rights consciousness; welfare regimes; dualization; Portugal

1 University of Cambridge, fcs23@cam.ac.uk

2 Loughborough University, L.J.Valadez@Lboro.ac.uk 


\section{Introduction}

In times of austerity, welfare states are often called into question. The current era of austerity in Europe is no exception. Especially since 2009, there has been a heated debate involving governments, policy-makers, and the public at large on the future of the welfare state in Europe. Political debate and decision-making benefit from detailed and up-dated knowledge concerning people's preferences. Hence the main question of this paper: What are people's welfare preferences in a context of economic crisis and austerity? This question is important for at least two reasons. First, income redistribution by the government is a central feature of all industrialized countries. Over the course of the twentieth century, and particularly since the Second World War, political and economic modernization entailed a dramatic expansion of public social welfare programmes, that is, the fundamental instrument of income redistribution by the government alongside fiscal policies. Second, political conflicts over redistribution, already one of the most contested issues in democracies, tend to become more acute in times of austerity. In crisis-ridden Europe, most political debates, at the national and supra-national levels, revolve around income redistribution trade-offs. This is especially the case in southern European countries such as Greece and Portugal, where such trade-offs have become all the more obvious as austerity policies imposed by international lenders made social expenditure a preferred target, including pension reforms, unemployment subsidies, and health care benefits. Moreover, there is mounting evidence that the general public's preferences regarding welfare provision seem amenable to change in difficult times (e.g. Ervasti et al. 2012; Fridberg 2012). Experiencing the worst economic crisis in a generation while being forced by international lenders to implement unprecedented welfare retrenchment programmes, Greece and Portugal provide excellent case studies with which to study evolving attitudes towards welfare.

This paper focuses upon Portugal, which requested international financial assistance 
in April 2011 from a troika of organizations including the European Commission, the European Central Bank, and the International Monetary Fund. Portugal provides an ideal case study for testing the resilience of universalistic understandings of welfare provision. This paper offers an analysis of the distribution of social attitudes towards the welfare state in Portugal, two years into the implementation of the austerity programme imposed by international lenders. The democratic Portuguese welfare state was erected according to strictly universalistic terms and it has never been seriously contested by neoliberal ideas. The troika's intervention marks the first attempt to restructure the Portuguese welfare state according to non-universalistic principles.

Portugal inaugurated the third wave of democratization in the late twentieth century with the Carnations Revolution of April 25, 1974 (Huntington 1991). The new democracy defined itself in terms of a break with the Estado Novo, a corporativist dictatorship created in 1933, and oriented towards European social democratic and socialist models. This is particularly obvious as regards public social provision. The Portuguese Constitution of 1975 contains what is still the longest and most detailed section on social rights in the world (BenBassat and Dahan 2008), with a strong emphasis upon principles of generality, gratuity, decentralization, and universalism. Social rights were no longer to be conceived as prerogatives of certain occupational groups, but as citizenship entitlements to be enjoyed by all citizens. These constitutional promises had institutional implications. The democratic welfare state was implemented in broadly universalistic terms, with universal public systems in the domains of health care, social security, and education (Vieira and Silva 2010; 2013). As in other southern European countries, however, such universalistic promises conflict with the high degree of fragmentation, familialism, and persistent gaps in social provision that characterize the Portuguese welfare state (Ferrera 1996, 1997; Mingione 2001; Rhodes 1997; Trifiletti 1999; Karamessini 2008). The Portuguese welfare state can thus be described as 
belonging to a southern European sub-type of the Continental state-corporatist model, in which universalistic elements predominate despite the persistence of clientelist and corporatist elements leading to fragmentation (Guibentif 1996; see also Leibfried 1993 on a Latin-Rim welfare model). The existing survey-based literature on Portuguese welfare attitudes lends support to this description (Cabral 1997). Briefly, this is the background against which the first attempt at the systematic restructuring of the Portuguese welfare state along non-universalist principles, embodied in the May 2011 Memorandum of Understanding on Specific Economic Conditionality between the Portuguese government and the troika of international lenders, was signed.

This study utilizes individual-level data from a survey applied to a representative sample of the Portuguese adult population in the spring of 2013 to explore attitudes in a context of welfare cuts resulting from the troika's intervention. The dependent variable is the opinion on which social rights should be universally guaranteed in a context of austerity. The main argument is that there are at least two sources of preference-formation regarding public social provision. According to the first logic, if one considers that social rights are inherent in human nature and core components of citizenship, one would favour a universalistic view in which everybody deserves access to social rights, irrespective of the level of individual contribution. In broad terms, this is the understanding enshrined in the Portuguese Constitution, consistently upheld by the Constitutional Court's jurisprudence since 1982, and which inspired the establishment of a universalistic social protection system, including a National Health Service primarily financed by taxation. According to the second logic, if one is aware that social rights imply obligations, one may favour a targeted view in which the enjoyment of social rights is based upon the extent of one's individual contribution and need. This logic inspired the old dictatorial regime's social provision schemes, defined largely in corporatist terms, which, albeit with important differences, can also be found in the troika's 
policy preferences. In this paper, we explore both logics to explain individual-level support for the public provision of education, health care, social security, and housing in a context marked by fiscal austerity and the (historically unprecedented) political questioning of the universalist character of public social provision.

The article is organized as follows. Section 2 presents the hypotheses and positions them amid the literature of welfare preferences: the dualization hypothesis (H1), the regime hypothesis (H2), and the social rights consciousness hypothesis (H3). In section 3, we discuss the data collection and the selection of variables, and present the regression models mobilized to test the hypotheses. In section 4 , we examine the results of the regression analyses and discuss these findings by reference to the literature. We conclude with an overview of our findings and suggestions for future research. 


\section{Literature Review and Hypotheses}

The first hypothesis takes its inspiration from recent literature on the 'dualization' of advanced post-industrial societies (Häusermann and Schwander 2010; Rueda 2005), which suggests western populations are increasingly divided into two groups with contrasting job market performances. On the one hand, we have the 'outsiders', which include those unemployed or with an unstable employment record. On the other hand, there are the 'insiders', who typically enjoy stable employment and have relatively long contributory careers. Inspired by zero-sum games, this hypothesis holds that both insiders and outsiders favour income redistribution by the government in times of austerity, but for different reasons and with different objectives in mind. This means that authorities have to choose different, indeed opposing, policy mixes to satisfy the demands of these two increasingly separate sectors of society.

By stipulating that the labour market cleavage coalesces into stable yet contrasting sets of interests and preferences, thus consolidates the aforementioned trend towards societal dualization, this hypothesis builds upon a materialist conception of human agency primarily motivated by self-interest. Self-interest has long been found to be a major determinant of welfare attitudes (Baslevent and Kirmanoglu 2011; Reeskens and van Oorschot 2013). Some studies have lent empirical support to the idea that dualization is primarily driven by motivations of self-interest. Blekesaune, for instance, has found that self-interest motivates social groups which are, or are likely to become, recipients of welfare state programmes, to adopt more positive attitudes towards these policies than those less likely to receive them (2007: 394). This has led dualization scholars to hypothesize that it is primarily for reasons of self-interest that outsiders 'prefer policies that allocate resources based on need, rather than contribution-payments', while insiders favour: 'policies that reward their - more continuous and stable - labour market performance’ (Häusermann and Schwander 2010: 3). Portugal 
seems to be a suitable case to test the robustness of this conjecture. This is for two reasons. First, the combination of a highly fragmented social protection system and a dual labour market has been seen in the last couple of decades to lead to increasing 'dualization' between well-protected beneficiaries and a growing number of unprotected individuals (Moreno 2006). Second, the circumstance that the austerity programme associated with the 2011 bailout led to both a net reduction of available income for pensioners (a typical insider's concern), and to record high unemployment rates (a typical outsider's issue), may have reinforced the trend towards the dualization of Portuguese society and fuelled dichotomous public support for welfare policies. Hence our first hypothesis (H1): when asked which social rights should the government guarantee even in hard times, the insiders' choice is expected to favour contribution-based welfare models (e.g. pensions of reform), while outsiders are expected to favour need-based welfare models (e.g. unemployment benefits).

Second, the 'regime' hypothesis suggests that welfare state types filter the effect of austerity on attitudes (e.g. Ebbinghaus 2012). Institutionalists draw upon the general hypothesized relationship between welfare regimes and support for redistribution (EspingAndersen 1990, 1999). According to this literature, the relative level of public support for redistribution in Portugal's southern European state-corporatist model is expected to be somewhere between the highly redistributive Social Democratic regime and the residual Liberal regime type (e.g. Arts and Gelissen 2001; Trifiletti 1999). The existing empirical literature, however, has had difficulty verifying how welfare attitudes consistently differ across countries (Jaeger 2006). This seems to be less of a problem in certain single-case studies where welfare attitudes have been found to broadly agree with the respective welfare type. For instance, available data on Portuguese social attitudes dating back to the 1990s shows, alongside support for complementary, contributory schemes, even more significant popular support for universalistic welfare provision (Cabral 1997, 2000). In sum, there are 
strong reasons, both attitudinal and historical-institutional, for one to expect the majority of the Portuguese population to prefer a universal welfare state. Our second hypothesis (H2) is thus that respondents are generally more likely to choose the universalistic, all-rights option than any of the other more contributory understandings.

Third, there is the 'social rights consciousness' hypothesis according to which the consciousness of social rights mediates structural events, such as the eventuality of austerity, and social attitudes towards welfare policies and principles (for an overview, see Hertogh 2004). This hypothesis is partly driven by two circumstances. First, besides prompting institutional and legal reform, the current crisis has led to a noticeable increase in the frequency of debates over welfare reform in the Portuguese media. Never has the Portuguese population been exposed to such detailed and heated debate on welfare reform and retrenchment as it has since the 2011 bail-out and subsequent austerity policies, including dozens of books, newspapers reports and editorials, television specials, as well as numerous academic seminars, conferences, and workshops. Second, the recent rise in protest activities in Portugal in response to austerity measures and welfare cuts (Baumgarten 2013) is likely to have contributed to an increase in Portuguese awareness of what social rights mean and what welfare provision implies, i.e. 'social rights consciousness'. Social rights consciousness has been recently defined as: 'the ways in which people act towards and think about rights' (Silva 2013: 11). As a sub-set of legal consciousness, 'social rights consciousness' is not a mere preference for rights (Ewick and Silbey 1998). Rather, it refers to a multidimensional understanding of rights as relational, reflexive, and contested. To have a right is to enter a political relation, to belong to a community whose norms include that right as something anybody can assert and that everybody can recognize. Rights require every member of the political community to take both roles or positions involved in a rights relation, that of entitlement and that of the obligation to respect it - this is how rights help constitute 
individual political identities. Rights are contested not only within oneself (i.e., one's legal consciousness is a dialectical process, responsive to concrete action-problems in real world situations, which evolves over time potentially in contradictory ways), but between different selves (politicians, judges, and ordinary citizens, for example, often disagree about the interpretation and application of rights). This pragmatic understanding of rights, whereby rights refer to doing more than having, can be traced back to the work of the early twentieth century American social psychologist G.H. Mead (2011: 211-322). We operationalize this concept through indicators measuring each of its three components. Our survey includes a block of original questions tackling the various trade-offs associated with social rights (relational), the frequency with which one thinks about and discusses them (reflexive), and their genealogy (contested). Given the revolutionary, left-of-centre historical origins of the democratic welfare state in Portugal, the third hypothesis (H3) is that the more prevalent social rights consciousness is, the more likely respondents are to follow a universalistic logic of preference-formation. This differs from the dualization and type of regime hypotheses above insofar as it does not suppose congruence between socio-economic attributes or macroinstitutional solutions and social attitudes. Rather, it determines that those social rights which are to be guaranteed by the government even in hard times are understood to stem from the respondent's practical knowledge. As far as we know, this is one of the few attempts to incorporate legal consciousness into the study of welfare attitudes in Europe, and is certainly the first to apply it to the study of welfare attitudes in Portugal. 


\section{Data and Methods}

Our data emerges from an original and nationally representative survey of the Portuguese population on citizen rights and obligations, governmental responsibility towards welfare and social provision, and welfare arrangements. The survey replicates some parts of the 2008 module on welfare attitudes of the Fourth Round of the European Social Survey (ESS), to which it adds blocks of questions from pre-existing surveys (International Social Survey Programme 2004), as well as new ones (e.g. questions on 'social rights consciousness'). As far as we know, this is the first time that part of the 2008 ESS module on welfare attitudes has been replicated at the country level. The questionnaire has 62 closed questions. The sample comprises 1,258 adults and fieldwork took place in the spring of 2013. The sample has been nationally and regionally weighted to represent the country's five main regions (North, Centre, Lisbon, Alentejo, and the Algarve). Respondents were interviewed according to random selection in each region, following quotas for gender, age, level of education, and occupation. A survey company especially hired and trained conducted face-to-face interviews at respondents' homes. The pre-test, comprising 15 interviews in Lisbon and Porto, was carried out in March 2013. Fieldwork took place between 8 and 30 April 2013. ${ }^{3}$ Descriptive statistics of the sample are summarized in Table 1.

[Table 1 here]

\subsection{Variables}

The dependent variables are about which social rights people believe should be protected from welfare retrenchment. We derive them from the following survey question: 'If the government had to reduce social spending, which of the following rights do you consider

\footnotetext{
${ }^{3}$ A copy of the questionnaire is available from the authors upon request.
} 
should be guaranteed to all citizens regardless of their level of income: social security, education, health, housing'. Respondents were asked to choose none, one, two, three, or all four rights in the list. We believe that, given the situation of austerity fatigue in Portugal at the time when the survey was deployed, if we were to ask people directly 'what rights to cut' this would elicit biased responses by prompting people to assume that rights had to be cut. To avoid this bias, we phrased the question in positive terms. It is assumed that choosing all four rights or three rights points to a universalistic understanding of the welfare state. That is, respondents are thought to subscribe to a general, overarching state responsibility for social provision. Conversely, we take all other answers (none, one, or two rights) to reflect a contributory understanding of public social provision, with certain social risks or vulnerabilities given priority over others.

The independent variables include reported political participation, ideology, social rights consciousness, and socio-economic controls. The independent variables are aligned with the hypotheses and with findings in previous studies, which have found them to be significant determinants of social attitudes concerning the role of government in social provision (Algan, Cahuc, and Sangnier 2011; Foster and Kaminska 2012; Roosma, Gelissen, and van Oorschot 2013; Schwander and Häusermann 2013), in redistribution (Jaeger 2009; León 2012; Stegmueller et al 2012), in government measures to promote equality, security, and opportunity (Taylor-Gooby 2011).

Political participation and ideology is studied by means of the following variables: Whether the respondent has either contacted a politician, worked in a party, signed a petition, participated in a demonstration, gone on strike, or written in social media on rights in the last 12 months; self-identification with the political spectrum; how important it is to vote; how important it is to participate in social organizations; average level of agreement with sentences: each citizen should enjoy education/health/social services in proportion to 
contributions; pessimistic view of the future of the education, health, and social security systems in Portugal; thinking that welfare systems are a burden to the country's economy; average opinion between what should be part of a democracy: be able to give opinion, be able to engage in an act of social disobedience, be able to go on general strike; opinion between: the government should reduce taxes and social spending or the government should increase taxes and social spending; and opinion on unemployment benefit: those who earn more should get higher unemployment benefit, or those who earn less should get higher unemployment benefit, or everybody should get the same unemployment benefit.

The variables related to social rights consciousness are opinions concerning factors which have contributed the most to guaranteeing social rights in Portugal; the frequency with which the respondent thinks or talks about welfare issues; whether, when going to a health centre, the respondent thinks that their taxes are funding the service, and the level of agreement that one can only enjoy social benefits if doing or giving something in exchange. Finally, socio-economic controls include: gender, age in years, level of education, household income, type of housing, employment status, and perceived income insecurity for the next 12 months (scale from 1 to 4). The complete list of independent variables is presented in Table 2.

[Table 2 here]

\subsection{Models}

The modelling strategy aims to capture four different opinions, each one representing perspectives on universalism-targeting spectrum, based on number of rights that people argued should be universally guaranteed even in times of crisis: choosing one right represents 
full targeting; choosing two represents targeting; choosing three rights represents universalism; and choosing all four rights represents full universalism. We created dummy variables for each type of response and used them as dependent variables in binary logistic regression models. Four binary logistic regression models were then constructed, one for each number of rights that people considered that should be universally guaranteed. The distribution of responses suggests that the sample is almost evenly split between those who chose a universalistic model and those who chose a contributory model. Models A and B (all four rights, three rights) include those who have more universalistic understandings of the welfare state. Together, these two models represent $48 \%$ of the sample $(27.4 \%$ and $20.1 \%$, respectively). In turn, models $\mathrm{C}$ and $\mathrm{D}$ reflect a more contributory understanding of welfare provision. Model C includes respondents who chose two rights that should be universally guaranteed. Model D is composed of respondents who chose only one right, which is the most contributory of our groups of opinion. Models C and D represent $50 \%$ of the sample ( $25.1 \%$ chose two rights, and $24.8 \%$ chose only one right ${ }^{4}$ ).

Only $2.6 \%$ of the sample chose no rights. 


\section{Discussion}

Results of the binary logistic models are provided in Table 3.

[Table 3 here]

Our findings partly confirm the 'dualization' hypothesis (H1). According to this hypothesis, periods of economic austerity, such as that which Portugal has experienced since 2011, are expected to lead to a dualization of welfare attitudes, separating 'insiders' from 'outsiders'. More specifically, we expected insiders to maximize their specific contribution-based expectations (e.g. pensions of reform), and outsiders to maximize their need-based demands (e.g. minimum guaranteed income, unemployment subsidy).

Our findings show that those currently unemployed in Portugal do tend to prefer more contributory need-based social policies, such as unemployment benefit or professional training, rather than a universalistic model. Concretely, those who are unemployed are 52\% less likely to choose the universalistic Model B (three rights) than those who have a job. In short, the unemployed in Portugal are 'outsiders' not only because of their objective labour market position but also owing to their distinctive views about how governments should address it. This seemingly 'aspirational' character of outsiderhood is one of the main findings of the paper. A second finding that supports $\mathrm{H} 1$ is the welfare attitudes of housewives and caretakers, another typical group of outsiders without stable employment and contributory careers. At first sight, our findings seem paradoxical. Housewives and caretakers were found to be simultaneously less and more likely to choose our two universalistic models. How to make sense of this? One possible interpretation brings us back to the very rationale behind the 'dualization’ thesis. Like unemployed people, housewives and caretakers are $80 \%$ less likely to choose Model B (three rights) than those who are employed since neither group has contributory careers which enable them to aspire to pensions of reform or health care 
schemes reserved for insiders. However, unlike unemployed people who have welfare policies specifically targeted at their condition, this group has no specially designed policy to look for. Hence it is not surprising that they also strongly support a universal model of welfare: Portuguese housewives and caretakers are 8.9 times more likely to choose Model A (four rights) than those who are employed. However interesting these findings are, the fact that we have not been able to identify similar attitudinal patterns on the part of insiders prevents us from fully confirming $\mathrm{H} 1$.

Our results also only partially confirm the 'regime' hypothesis (H2). Given the historical and institutional characteristics of the welfare state in Portugal, and taking into consideration past public opinion surveys, we expected respondents to choose the universalistic, all-rights option (Model A) rather than any of the other more contributory understandings.

Although almost $50 \%$ of the sample preferred universalistic models, the fact remains that not more than a quarter of the sample chose Model A. Several reasons may account for this. To begin with, this hypothesis has often proved to be difficult to test empirically. Previous studies have often failed or, at least, faced difficulties in using survey-based data to show significant differences across countries with different types of welfare regime (Jaeger, 2006). Although our case study does reveal a significant correspondence between welfare attitudes and regime type, this correspondence is lower than one could expect judging from the de jure features of the welfare state in Portugal. If one considers its de facto profile, however, things look very different. In fact, a second reason for our partial confirmation of H2 may well be related to the fragmentation arising from the confusing coexistence in Portugal of universalistic solutions and clientelist and corporatist elements. This line of reasoning is reinforced by a third set of reasons of a circumstantial nature. The current crisis has accelerated the process of transformation and reform of the Mediterranean type of 
welfare regime, raising additional doubts concerning the adequacy of the 'regime hypothesis' in tackling cases such as Portugal since the bail-out (Marí-Klose and Moreno-Fuentes 2013). In fact, it seems that there may be a growing targeted 'Anglo-Saxon' style of welfare, given that a quarter of the respondents chose to universally guarantee only one right, and around $3 \%$ chose no rights at all.

Our data confirms the 'social rights consciousness' hypothesis (H3). Given the genealogy of social rights in Portugal, and the unprecedented levels of public deliberation over the future of the welfare state, we expected that the prevalence of 'social rights consciousness' would be positively correlated with universalistic preferences regarding social provision.

Social rights consciousness was found to determine, at least to a certain extent, inclusion in the universalistic Models and B. In particular, inclusion in Models A and B is explained by the relational and contested components of social rights consciousness. Believing that one can only enjoy social rights by giving or doing something in exchange is negatively associated with choosing Model A (each 10\% agreement with the former is associated with $11 \%$ less likelihood of the latter). In turn, to believe that social rights exist in Portugal because they are guaranteed by the Constitution is associated with $80 \%$ higher likelihood of choosing Model B, and believing that they exist because unions have pressured the government is associated with twice the likelihood of choosing this same model. In short, a pragmatic understanding of social rights as both fundamental and absolute (as opposed to negotiable and conditional), and the result of concrete political struggles (as opposed to an idealistic understanding of rights), seems to shape individual preferences for universalistic models of welfare.

Social rights consciousness also seems to determine inclusion in the contributory 
Models C and D, although in a different way from that of the universalistic models. Concretely, inclusion in Models C and D is mainly determined by the historically specific consciousness of the contested nature of social rights in Portugal. Whereas believing in the positive role of the (universalistic) Constitution of 1975 is associated with $55 \%$ less likelihood of choosing Model D (only one right), thinking that social rights in Portugal exist because they have been agreed between the government and the private sector makes one 2.6 times more likely to choose Model C (two rights) than those who do not think this way. A more privatistic social rights consciousness is thus found to lie behind individual preferences for contributory models.

Underlying individual choice for more universalistic and more contributory models seems to be a consistent set of ways of thinking and talking about social rights. More than the reflective dimension of social rights consciousness, our findings suggest that it is its relational, and especially its contested nature, that matters. In the case of Portugal, this component is closely related to the political history of the democratic welfare state and the role that certain institutions and political actors have performed in claiming, implementing, and fighting for social rights. Concretely, it seems that the prioritizing of certain key social rights relies more upon their status as constitutional entitlements than upon fickle democratic political arrangements. This trumping of constitutionalism over democracy is perhaps associated with both popular dissatisfaction with party politics, confirmed by successive opinion polls in recent years, and the positive association in the public mind between the Portuguese Constitution and the universalistic protection of social welfare benefits and entitlements. Our findings give credence to this line of reasoning. Inclusion in the fully universalistic Model A is determined by a rejection of representative democracy and the party system (each $10 \%$ increase in agreeing that voting is important is associated with $10 \%$ less probability of choosing this model), and a concomitant endorsement of more horizontal and 
informal forms of political participation (each 10\% increase in thinking that it is important to take part in social organizations is associated with an $18 \%$ increase in the latter). Informing choice between universal and contributory models of public social provision one finds certain ways of thinking and acting towards rights, which, in turn, seem closely related to ideas about political history and agency, as well as to concrete forms of political participation. 


\section{Conclusion}

In this article we have examined how social attitudes towards the welfare state fare under conditions of economic austerity. It utilizes original data from a customized survey conducted in Portugal in spring 2013, approximately two years after the country benefited from a €78 billion bail-out on condition that Lisbon made extensive cuts to public expenditure, including social welfare provision. After several decades of welfare state expansion, involving the enactment of popular policies within a broad political consensus, this was the first time the Portuguese authorities needed to enact the unpopular 'new politics of welfare retrenchment' (Pierson 1996) in a context marked by the troika's external intervention, substantial political mobilization, and vocal opposition to welfare retrenchment by established interest groups, opposition political parties, and the Constitutional Court. This article provides the first systematic analysis of social welfare attitudes in Portugal under these new conditions. Besides using original data to tackle a relevant topic, the article introduces an original approach into a well researched field. In particular, we have (a) tested some of the most important hypotheses in the literature, and (b) devised and tested a hypothesis of our own.

First, we have shown that Portugal is an increasingly dualized society, and that the Portuguese tend to think of welfare provision along the lines of this new cleavage. In particular, outsiderness emerges from our study as a category whose salience is as much related to one's job market performance, as it is to the possibility of aspiring to concrete social policies. This finding can contribute to correct the underlying materialism of some of the ‘dualization’ scholarship, which sees insiderness and outsiderness as individual attributes arising from specific labour market careers, rather than as floating signifiers in which we all potentially fit at one point or another. From this angle, insiderness is a system of classification not unlike those of age, gender, race, or class, with which it intersects in individual biographies and collective experiences. Future studies should explore this finding, 
both longitudinally (e.g. before and after the crisis), and cross-nationally (e.g. to identify possible common patterns among Southern European countries). In addition, qualitative studies should be used to analyse the dualization of European societies in more detail. For instance, it would be useful to shed light on the processes through which social agents become 'outsiders' or 'insiders' in different periods of their lives as a result of certain life choices or eventualities, and how this intersects with their gender, ethnicity, and class position.

Another hypothesis in the literature tested here was the 'regime' hypothesis. Our results show that there is a significant and substantial correspondence between the type of welfare regime in Portugal and social welfare attitudes. This was not enough, however, to fully confirm this hypothesis and we adduced several reasons why this may be the case, including the well known gap between the impact of macro-level institutional arrangements and micro-level survey data.

In the third hypothesis, we explored a possible solution to this difficulty in the form of the pragmatic concept of 'social rights consciousness'. Although an individual-level variable, social rights consciousness is aimed at capturing the practical knowledge of respondents, which is not reduced to individual preferences. Also, by focusing upon inherently creative ways of doing and thinking, it exceeds the impact of macro-structural factors. Incidentally, this was the only hypothesis confirmed by our data. In Portugal in 2013, the more conscious one is of the contested nature of social rights, the more likely one is to reject contributory understandings of welfare and to endorse universalistic ones. This is one of the chief contributions of this paper. Whilst 'legal consciousness' has long been used in qualitative and quantitative studies, especially in the United States, its inclusion in the literature of European welfare politics, mainly focused either upon individual socio-economic characteristics or institutional variables, is still limited. Although circumscribed to one country and a single 
year, our results suggest that this neo-Meadian variable be included in future comparative and longitudinal studies of welfare attitudes.

In sum, in this paper we have presented an overview of the social attitudes of the Portuguese towards the welfare state at a time when they were confronted with a hard choice. The title of the paper takes its inspiration from William Styron's 1979 novel Sophie's Choice about a woman offered the choice by a Nazi concentration camp officer of saving the life of one of her two children at the expense of the other. Whilst less extreme than Sophie's choice, the choice the Portuguese faced in 2013 was nevertheless painful and equally imposed by an external party. This choice was that of a new politics of welfare retrenchment or bankruptcy. For the purposes of this paper, we reformulated this choice in terms of which social rights people believe should be protected from welfare retrenchment. The Portuguese choice, our findings suggest, has been shaped in part by individual labour market performance, in part by a historical-institutional orientation towards universalism, and to a significant extent, by social rights consciousness. Only time will tell if their decision will prove as difficult to live with as Sophie’s choice. 


\section{References}

Algan, Y., Cahuc, P. and Sangnier, M. (2011) 'Efficient and inefficient welfare states’, IZA Discussion paper No. 5445. Germany.

Arts, W. and Gelissen, J. (2001) 'Welfare States, Solidarity and Justice Principles: Does the Type Really Matter?’, Acta Sociologica, 44, 283-299.

Baumgarten, B. (2013) ‘Geração à Rasca and beyond: mobilizations in Portugal after 12 March 2011', Current Sociology 61: 457-73.

Ben-Bassat, A. and Dahan, M. (2008) 'Social rights in the constitution and in practice', Journal of Comparative Economics 36: 103-119.

Blekesaune, M. (2007) 'Economic Conditions and Public Attitudes to Welfare Policies', European Sociological Review 23(3), 393-403.

Cabral, M.V. (1997) Cidadania Política e Equidade Social em Portugal. Oeiras: Celta.

Cabral, M.V. (2000) ‘O exercício da cidadania política em Portugal’, in M.V. Cabral, J. Vala \& J. Freire (eds.) Trabalho e Cidadania. Lisbon: Imprensa de Ciências Sociais.

Ebbinghaus, B. (2012) 'Comparing welfare state regimes: Are typologies an ideal or realistic strategy?', Paper presented at European Social Policy Analysis Network, Edinburgh, UK September 6-8.

Ervasti, H., Andersen, J., Fridberg, T., and Ringdal, K. (2012) The Future of the Welfare State. London: Edward Elgar.

Esping-Andersen, G. (1990) The Three Worlds of Welfare Capitalism. Princeton: Princeton University Press. 
Esping-Andersen, G. (1999) Social Foundations of Post-Industrial Economies. Oxford: Oxford University Press.

Ewick, P. and Silbey, S.S. (1998) The Common Place of Law. Chicago: University of Chicago Press.

Ferrera, M. (1996) 'Southern Model of Welfare in Social Europe', Journal of European Social Policy 6(1): 17-37.

Ferrera, M. (1997) 'The Uncertain Future of the Italian Welfare State', West European Politics 20(1): 231-249.

Foster, F. and Kaminska, M. (2012) 'Welfare State Values in the European Union, 20022008', Journal of European Public Policy 19(6): 900-920.

Fridberg, T (2012) 'Legitimacy of the system and support for the welfare state'. In Ervasti, H. et al. (eds) The Future of the Welfare State. London: Edward Elgar, pp. 134-152.

Guibentif, P. (1996) 'The Transformation of the Portuguese Social Security System’. In M. Rhodes (Ed.) Southern European Society and Politics, Special Issue on Southern European Welfare States, 1(3): 219-239.

Häusermann, S. and Schwander, H. (2010) 'Explaining Welfare Preferences in Dualized Societies'. Paper presented at the 17th Conference of Europeanists in Montréal, Canada. Available at: http://www.schwander-hanna.ch/files/Hausermann_Schwander_CES2010.pdf Hertogh, M. (2004) ‘A ‘European’ Conception of Legal Consciousness’, Journal of Law and Society 31(4): 457-481.

Huntington, S. (1991) The Third Wave. Norman, OK: University of Oklahoma Press.

Jaeger, M. (2006) 'Welfare Regimes and Attitudes Towards Redistribution', European 
Sociological Review 22(2): 157-170.

Jaeger, M. (2009) 'United but divided: welfare regimes and the level of variance in public support for redistribution', European Sociological Review 25(6): 723-737.

Karamessini, M. (2008). 'Continuity and Change in the Southern European Social Model', International Labour Review 47(1): 43-70.

Leibfried, S. (1993) 'Towards a European Welfare State?', in C. Jones (ed) New Perspectives on the Welfare State in Europe. Abingdon: Routledge, pp. 133-156.

León, F. (2012) 'Reciprocity and Public Support for the Redistributive Role of the State', Journal of European Social Policy 22(2): 198-215.

Marí-Klose, P. and Moreno-Fuentes, F. (2013) 'The Southern European Welfare model in the post-industrial order', European Societies 15(4): 457-492.

Mingione, E. (2001) 'The Southern European Welfare Model and the Fight against Poverty and Social Exclusion’ in Tolba M.K. (ed.) Our Fragile World. Challenges and Opportunities for Sustainable Development, Oxford: EOLSS Publishers, pp.1041-51.

Mead, G.H. (2011) G.H. Mead. A Reader. F.C. Silva (ed.), Abingdon: Routledge.

Moreno, L. (2006) 'The Model of Social Protection in Southern Europe: Enduring Characteristics?’, Revue Française des Affaires Sociales 5: 73-95.

Pierson, P. (1996) 'The New Politics of the Welfare State', World Politics 48(2): 143-179.

Rhodes, M. (1997) 'Southern European Welfare States, Identity, Problems and Prospects for Reform', in M. Rhodes (Ed.), Southern European Welfare States: Between Crisis and Reform, London: Frank Cass, pp. 1-22. 
Roosma, F., Gelissen, J. and van Oorschot, W. (2013) 'The Multidimensionality of Welfare State Attitudes’, Social Indicators Research 113(1): 235-55.

Schwander, H. and Häusermann, S. (2013) 'Who is in and who is out?', Journal of European Social Policy 23: 248-269.

Silva, F.C. (2013) 'Outline of a social theory of rights: A neo-pragmatist approach', European Journal of Social Theory 14(4): 1-19.

Stegmueller, D., Scheepers, P., Rossteutscher, S., de Jong, E. (2012) 'Support for redistribution in Western Europe’, European Sociological Review 28(4): 482-97.

Taylor-Gooby, P. (2011) ‘Security, Equality, and Opportunity’, Journal of European Social Policy 21: 150-63.

Trifiletti, R. (1999) 'Welfare Regimes and the Worsening Position of Women', Journal of European Social Policy, 9: 49-64.

Van Oorschot, W., Reeskens, T. and Meuleman, B. (2012) 'Popular Perceptions of Welfare State Consequences', Journal of European Social Policy 22(2): 181-97.

Vieira, M.B. and Silva, F.C. (2010) O Momento Constituinte. Coimbra: Almedina.

Vieira, M.B. and Silva, F.C. (2013) 'Getting Rights Right', International Journal of Constitutional Law 11(4): 898-922. 
Table 1. Descriptive statistics of the sample

Characteristic

\begin{tabular}{rll}
\multicolumn{1}{c}{ Gender } & Male & $45.8 \%$ \\
& Female & $54.1 \%$ \\
\hline Age & 18 to 24 years & $9.3 \%$ \\
& 25 to 34 years & $16.7 \%$ \\
& 35 to 44 years & $17.7 \%$ \\
& 45 to 54 years & $18.3 \%$ \\
& 55 to 64 years & $15.5 \%$ \\
& 65 years or more & $22.5 \%$ \\
Employment status & Employed & $42.6 \%$ \\
& Unemployed & $18.9 \%$ \\
& Pensioner & $28.1 \%$ \\
& At home / student & $9.0 \%$ \\
& Other & $1.4 \%$ \\
\hline Level of education & Completed primary school & $9.4 \%$ \\
& Completed up to secondary school & $26 \%$ \\
& Completed high school & $14 \%$ \\
& Completed general or technologic studies & $28.2 \%$ \\
& Completed some technical specialisation & $13.4 \%$ \\
& Completed higher education & $9 \%$ \\
\hline & Own and paid for & $34.8 \%$ \\
& Own and paying the credit & $24.2 \%$ \\
& Rented (pre-1990 scheme) & $11.1 \%$ \\
& Rented (post-1990 scheme) & $23.8 \%$ \\
& Other & $6 \%$ \\
\hline
\end{tabular}

Source: Original survey. Sample size: 1,258 adults in Continental Portugal. 
Table 2. Independent variables used in the regression models

\begin{tabular}{|c|c|}
\hline \multirow{3}{*}{$\begin{array}{r}\text { Domain } \\
\begin{array}{r}\text { Political } \\
\text { participation }\end{array}\end{array}$} & \\
\hline & $\begin{array}{l}\text { Whether the respondent has either contacted } \\
\text { a politician, worked in a party, signed a } \\
\text { petition, participated in a demonstration, } \\
\text { gone on strike, or written in social media on } \\
\text { rights in the last } 12 \text { months. } \\
\text { Self-identification in the political spectrum. } \\
\text { How important it is to vote. }\end{array}$ \\
\hline & $\begin{array}{l}\text { How important it is to engage in social } \\
\text { organisations. }\end{array}$ \\
\hline $\begin{array}{l}\text { Welfare } \\
\text { ideology }\end{array}$ & $\begin{array}{l}\text { Level of agreement with the phrases: "each } \\
\text { citizen should enjoy education in proportion } \\
\text { to contribution; each citizen should enjoy } \\
\text { health services in proportion to contribution; } \\
\text { each citizen should enjoy social security in } \\
\text { proportion to contribution”. } \\
\text { Whether (1) the education system (2) health } \\
\text { services (3) social security in Portugal will } \\
\text { not be able to be maintained, will be } \\
\text { maintained, or be improved. } \\
\text { Level of agreement: welfare systems are a } \\
\text { burden to the country's economy. } \\
\text { How important it is for a democracy: to be } \\
\text { able to give opinion, to be able to engage in } \\
\text { social disobedience act, to be able to go on } \\
\text { general strike. } \\
\text { Preference between lower taxes and lower } \\
\text { social spending, or higher taxes and higher } \\
\text { spending. } \\
\text { Opinion on unemployment benefit. }\end{array}$ \\
\hline
\end{tabular}

Values

Yes/No indicating whether respondent has done either of these actions.

Left/Centre/Right.

Continuous values from 1 (total

disagreement) to 7 (total agreement).

Continuous values from 1 (total

disagreement) to 7 (total agreement).

Each question could take values from (1 total disagreement) to 7 (total agreement). New variable was created to compute the average of the three.

New "pessimism" variable was created: if respondent thought the three systems will not be able to be maintained.

Continuous values from 1 (total disagreement) to 7 (total agreement). Each question could take values from (1 total disagreement) to 7 (total agreement). New variable was created to compute the average of the three. Continuous values from 0 (reduce taxes and social spending) and 10 (increase taxes and social spending).

Four options: those who earn more should get higher unemployment benefit, or those who earn less should get higher unemployment benefit, everybody should get the same unemployment benefit, other arrangement.

Social rights How often "do you think or talk about Three options: never, sometimes, often. consciousness welfare issues such as education, health, pensions".

How often "do you follow the news on Three options: never, sometimes, often. welfare issues such as education, health, pensions".

"When going to a health centre, do you think that your taxes are funding the service". Level of agreement: "One can only enjoy Two options: Yes/ no. social benefits if doing or giving something

Continuous values from 1 (total disagreement) to 7 (total agreement). 


\begin{tabular}{|c|c|c|}
\hline & \multicolumn{2}{|l|}{ in exchange”. } \\
\hline & \multicolumn{2}{|l|}{ They are found in the Portuguese } \\
\hline & Constitution. & Two options: Yes/ no. \\
\hline & Workers fought for them. & Two options: Yes/ no. \\
\hline & Portugal is a Democracy. & Two options: Yes/ no. \\
\hline & There is pressure from the unions. & Two options: Yes/ no. \\
\hline & $\begin{array}{l}\text { A pact between the government, private } \\
\text { sector, and unions. }\end{array}$ & Two options: Yes/ no. \\
\hline & Portugal joined the European Union. & Two options: Yes/ no. \\
\hline \multirow{7}{*}{$\begin{array}{r}\text { Socio-economic } \\
\text { controls }\end{array}$} & Gender. & Male/female \\
\hline & Age. & Continuous, in years. \\
\hline & Level of education. & $\begin{array}{l}\text { Up to primary school. } \\
\text { Completed up to secondary school. } \\
\text { Completed high school. } \\
\text { Completed general or technologic } \\
\text { studies. } \\
\text { Completed some technical } \\
\text { specialisation. } \\
\text { Completed higher education. }\end{array}$ \\
\hline & Household income & $\begin{array}{l}\text { Continuous OECD equivalised total } \\
\text { household income. }\end{array}$ \\
\hline & Type of housing & $\begin{array}{l}\text { Own and paid for. } \\
\text { Own and paying the credit. } \\
\text { Rented (pre-1990 scheme). } \\
\text { Rented (post-1990 scheme). } \\
\text { Other. }\end{array}$ \\
\hline & Employment status & $\begin{array}{l}\text { Employed. } \\
\text { Unemployed. } \\
\text { Pensioner. } \\
\text { At home / student. } \\
\text { Other. }\end{array}$ \\
\hline & $\begin{array}{l}\text { Perceived income insecurity: consider } \\
\text { income will be sufficient in this year }\end{array}$ & Yes/no. \\
\hline
\end{tabular}

Source: Original survey. Sample size: 1,258 adults in Continental Portugal. 
Table 3. Binary logistic regression models

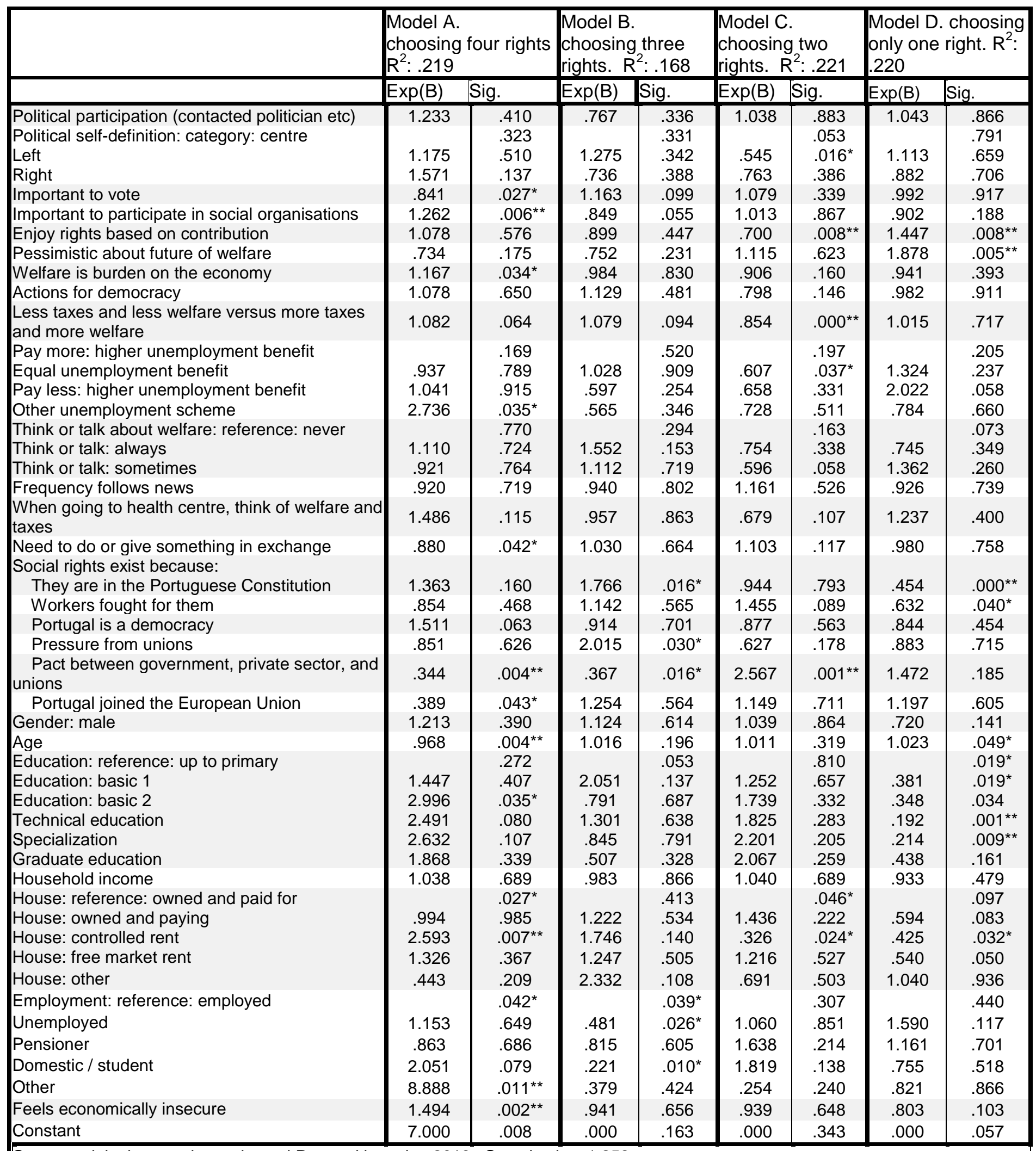

Source: original survey in continental Portugal in spring 2013. Sample size: $1,258$.

$\operatorname{Exp}(B)$ : Odds ratio of responding in such way (the dependent variable). For example: in Model A, those who think that it is important to participate in social organisations are $26 \%$ more likely to choose the four rights than those who do not think that way. Also, those who think that social rights exist thanks to a pact between the government, the private sector, and unions are $66 \%$ less likely to choose the four rights than those who do not.

* significant at .05 level $\quad * *$ significant at .01 level. 
